\title{
The Small-Sized Premium: Is it Really Relevant? Evidence from the European Equity Market
}

\author{
Renato Salvatore Camodeca ${ }^{1}$, Christian Prinoth $^{2} \&$ Umberto Sagliaschi $^{3}$ \\ ${ }^{1}$ University of Brescia, Department of Economics and Management, Italy \\ ${ }^{2}$ Quaestio Capital Management SGR SpA, Italy \\ ${ }^{3}$ University of Brescia, Department of Economics and Management, Quaestio Capital Management SGR SpA, Italy \\ Correspondence: Renato Salvatore Camodeca, University of Brescia, Department of Economics and Management, \\ Italy.
}

Received: July 29, 2020

Accepted: August 20, 2020

Online Published: August 24, 2020

doi:10.5430/afr.v9n3p85

URL: https://doi.org/10.5430/afr.v9n3p85

\begin{abstract}
The valuation of a company reflects the expected return-that is, the cost of capital that investors demand in exchange for the risk assumed. Despite the ex-ante nature of the problem, the majority of empirical analysis has focused on factors explaining expected returns from an ex-post perspective. In this paper, we take a different approach and try to identify which factors are ex-ante included in discount rates, with particular attention to the so-called size premium. Starting from observed market capitalizations and company fundamentals, we obtain the implied cost of capital from the reverse engineering of a carefully designed fundamental valuation model. Panel data regressions are used to investigate the existence of a relation between the implied cost of capital and the firm's size, including other control variables representative of the most cited asset pricing "anomalies." Our sample comprises European nonfinancial stocks listed on primary markets, with half-yearly observations starting from the aftermath of the 2008 global financial crisis. Contrary to common wisdom, we find that the firm's size has no tangible impact to explain the implied cost of capital.
\end{abstract}

Keywords: size premium, asset pricing, firm valuation, dynamic capital structure, implied cost of capital, factor anomalies

\section{Introduction}

In this paper, our purpose is to investigate whether a small-sized premium is present in the valuation of European listed companies. The idea that companies smaller than their larger competitors should on average generate higher stock-market returns has been in vogue since the early 1980s. Banz (1981) and Reinganum (1981) observed that small-caps outperformed on average the market index, and this motivated further empirical analysis that culminated in Fama and French's (1993) seminal paper, which set the basis for factor investing. Nevertheless, the existence of a size premium has not been exempt from critiques. Black (1993), and more recently A. Ang (2014) and C. Ang (2018), stressed most empirical studies, including that of Fama and French (1993), were descriptive analyses illustrating which factors better fit the cross-section of stock returns from an ex-post perspective. Our paper provides a humble contribution to the large body of existing literature. Building on the notion of implied cost of capital (Bini, 2018; Easton, 2007, 2016; Easton, Taylor, Shroff, \& Sougiannis, 2002), we assess whether European listed companies are valued, including a size premium. In doing so, we also examine whether other factors from the asset pricing anomaly literature, the so-called factor zoo (Feng, Giglio, \& Xiu, 2020), are priced in from an ex-ante perspective. Before proceeding further, we present an overview of the most relevant existing literature.

The natural starting point of the discussion is equilibrium (Note 1) asset pricing, which is the common denominator for everything that follows. Consider a financial asset with periodic stochastic cash flows $x(t)$. (Note 2) In equilibrium, there exists a stochastic process $\Lambda_{t}$, the so-called stochastic discount factor (SDF), such that the price of each asset must be consistent with the following equation:

$$
p_{t} \Lambda_{0}=\mathbb{E}_{t} \int_{0}^{\infty} \Lambda_{t+s} x_{t+s} d s
$$

Cochrane (2008) presents a simple although heuristic derivation of equation (1), while Dumas and Luciano (2017) and Ma (2011) provide formal proofs with different levels of generality, based on the original works of Duffie and 
Zame (1989) and Duffie and Skiadas (1994), respectively. Discount rates, or expected returns or cost of capital, are determined by equilibrium asset pricing, consistent with equation (1). To see this, note if we let $\mu_{t}$ be the instantaneous expected return of an asset,

$$
\mu_{t} d t:=\frac{1}{p_{t}}\left(x_{t} d t+d p_{t}\right)
$$

then the following identity always holds true:

$$
p_{t}=\mathbb{E}_{t} \int_{0}^{\infty} e^{-\int_{0}^{s} \mu_{t+h} d h} x_{t+s} d s .
$$

Because prices are determined in equilibrium by equation (1), expected returns constitute just a function of the covariance between $x_{t}$ and $\Lambda_{t}$. To some extent, the whole of empirical asset pricing literature can be reduced to the study of which factors can explain this covariance systematically, as remarked by Cochrane (2011).

The first and perhaps most famous model for $\mu$ is the capital asset pricing model (CAPM) developed by Lintner (1965), Mossin (1966), and Sharpe (1966). The CAPM predicts a linear relation between discount rates, namely

$$
\mu=r+\beta \lambda,
$$

where $r$ is the risk-free rate, $\beta$ denotes a security-specific constant, and $\lambda$ represents the market risk premium. The last is a function of the risk aversion of a representative agent and is equal to the expected excess return of the market portfolio, which must be held optimally by investors in equilibrium. If we interpret $\mu$ as the firm's cost of capital, then the coefficient $\beta$ may depend on variables such as the firm's sector and more generally form the covariance between the firm's free cash flows and the SDF.

Despite its wide adoption, the validity of the CAPM crucially depends on the implicit assumption of a constant investment opportunity set, (Note 3) which is far less innocuous than it might seem. Hellwig (1977) shows this assumption fails to be consistent with the capital market equilibrium in a dynamic setting with constant relative risk aversion (CRRA) investors, unless we assume an infinitely elastic supply of each asset.(Note 4) Cochrane, Longstaff, and Santa-Clara (2007) expand on Hellwig's critique and analytically derive the expression for the expected returns of two assets ("two trees") available in fixed supply, showing the existence of an endogenous momentum effect (Carhart, 1997) deriving from the collective inability to rebalance portfolios. Martin (2013) generalizes this analysis to the case of an arbitrary number of assets and shows how the momentum effect is likely to be relevant only for assets that have a very large weight in investors' portfolios.

If the opportunity set is not constant, then the classic CAPM does not hold in general. The variables affecting the distribution of asset returns influence individual portfolio decisions, as shown in Merton's (1973) intertemporal capital asset pricing model (ICAPM). In the ICAPM, the cost of capital may depend on factors other than the expected return of the market portfolio. Based on this premise, Fama and French (1993) empirically investigated in their seminal paper which factors had an additional explicative power in predicting equity returns. In the sample considered, they observed both size and value premiums; that is, companies with either lower market capitalization (market cap) or higher book-to-price ratio performed on average better than companies with higher market capitalization or lower book-to-price ratio, respectively.

Initially, the existence of size and value premiums was motivated heuristically; both factors were cited as proxies for higher business risk in the absence of arbitrage. Berk, Green, and Naik (1999) formalize this intuition in a partial equilibrium model with irreversible investment options. In their model, a linear combination of the book-to-price ratio and the inverse of the firm's market capitalization perfectly explains the firm's cost of capital. In particular, a higher book-to-price ratio reflects, ceteris paribus, riskier assets in place, while the size of the company is a measure of the relative weight of growth options, which by definition have larger tail risk compared with assets in place. Notably, if growth options are of limited or null value (for instance, in Leahy's [1993] general equilibrium), then size should no longer be a relevant factor to explain the firm's cost of capital.

From a more empirical perspective, several authors questioned the causal nature and consequently the existence of a size premium, as observed by Banz (1981), Reinganum (1981), and Fama and French (1993). Black (1993) was the first to notice that in the end, Fama and French's (1993) work was to some extent an ex-post exercise of data mining. Along this line, A. Ang (2014) documented that after 1980, the size premium was basically nonexistent; more recently, C. Ang (2018) showed a general practice of data mining in the majority of empirical works citing the existence of a size premium. On the practitioner side, Damodaran (2015) expressed his own skepticism of both the nature and the magnitude of the size premium.

We present empirical evidence supporting the lack of ex-ante evidence of a size premium by regressing the implied cost of capital obtained from the reverse engineering of a fundamental valuation model based on first principles. Our 
valuation model also includes a recent advancement in corporate finance literature, building on DeMarzo and He's (in press) work, which provides a simple guide to deal with the effect of time-varying leverage and discretionary debt issuance (e.g., share buybacks funded with additional debt). The empirical adoption of DeMarzo and He's (in press) framework has a precedent in the literature, despite its novelty. Chaderina, Weiss, and Zechner (2020) successfully used it to explain the maturity premium, defined as the observed excess return of a market-neutral portfolio which is long in firms with a long-maturity debt and short in firms with a short-maturity debt.

The remainder of this paper is organized as follows. In Section 2, we develop our fundamental valuation model and the notion of implied cost of capital, leaving the discussion of the most technical details to Appendices $\mathbf{A}$ and $\mathbf{B}$. In Section 3, we discuss the composition of our data set, the calibration of the valuation model to actual data, and the estimation of a panel data regression model to identify which factors are relevant to explain the implied cost of capital of European listed companies. In Section 4, we present the results of our empirical analysis and show the size premium is basically nonexistent from an ex-ante perspective. Finally, in Section $\mathbf{5}$ we draw our conclusions.

\section{Valuation and Implied Cost of Capital}

By definition, the value of a firm $(V)$ is the sum of all its financial liabilities at the net of cash reserves. As we show in Appendix A, we can always obtain $V$ as the sum of three distinct components: the value of assets in place $\left(V^{A}\right)$, the value of growth options $\left(V^{G}\right)$, and the value of debt tax shield $(D T S)$, minus the value of the expected bankruptcy costs $(B C)$; that is,

$$
V=V^{A}+V^{G}+D T S-B C .
$$

The previous equation is an evident application of equilibrium asset pricing, which is linearly additive in the cash flows generated by the firm, and the firm's budget constraint, where we can distinguish between the cash flows generated by the assets already in place and those coming from future growth options. In essence, in the absence of debt financing, the value of the firm is equal to the net present value of the cash flows generated by its already existing assets $\left(V^{A}\right)$, plus those coming from the exercise of valuable growth options $\left(V^{G}\right)$. The presence of debt necessarily results in the possibility of the firm's default, with the consequent loss of value due to the inefficiency of any restructuring, reorganization, or liquidation process. The expected value of this loss takes the name of expected bankruptcy costs $(B C)$. Reindl, Stoughton, and Zechner (2013) and Glover (2018) provide recent estimates of bankruptcy costs and show these might be considerably relevant. The introduction of debt financing may also affect investment decisions and in turn the value of growth options, as found by Myers (1977) and Jensen and Meckling (1976). These are the agency costs of debt. Both agency costs and $B C$ are at least partially offset by the value of debt tax shield (DTS): that is, the net present value of tax savings on interest expenses, which constitute a sort of additional component to the firm's total free cash flows.

In the real options literature, assets in place tend to depreciate and therefore produce less and less cash flows as time passes. This is consistent with the interpretation of "assets in place" as those already "physically" part of the firm's balance sheet. However, the way in which we split cash flows in the firm's budget constraint could be arbitrary in principle, and the previous interpretation is a bit stringent in reality. In this regard, we observe that revenue growth is divided into two broad categories: organic and nonorganic. The nonorganic part is the one related to M\&As, which we identify in our model as the firm's growth options. Thus, we include the effects of organic growth in the value of assets in place. This approach is motivated by the consideration that organic growth typically depends on macroeconomic factors and the sector, as well as the firm's current positioning. Stated differently, our approach recognizes that organic growth cannot be viewed as a financial option, in contrast to M\&A opportunities.

Our valuation model is based on the assumption that growth options for listed companies can be valued as equal to zero from an ex-ante perspective; that is, $V^{G}=0$. This assumption is backed by empirical evidence and consistent with proven theoretical considerations. We obtained data from FactSet for all the M\&A transactions that target a European company for the period 2010-2020, consistent with the sample considered in our analysis (see Section 3). Considering only $M \& A$ deals valued above 10 million euros and for which the target's valuation relative to its EbITDA (Note 5) were disclosed, we had a representative sample comprising more than 2,400 transactions. For each sector, we computed the median enterprise value-to-EbITDA (EV/EbITDA) multiple of all deals and compared it with the median of the same multiple for all the listed companies included in our sample (Table 1).

Table 1. Valuation of target companies versus market multiples of listed companies, Europe (2010-2020) 


\begin{tabular}{llll}
\hline FactSet sector & \multicolumn{1}{c}{$\begin{array}{c}\text { EV/EbITDA: } \\
\text { Valuation } \\
\text { (median) }\end{array}$} & $\begin{array}{l}\text { EV/EbITDA: } \\
\text { companies (median) }\end{array}$ & $\begin{array}{l}\text { Sisted } \\
\text { premium }\end{array}$ \\
\hline Commercial services & $10.91 \mathrm{x}$ & $9.19 \mathrm{x}$ & $18.75 \%$ \\
Communications & $9.18 \mathrm{x}$ & $6.29 \mathrm{x}$ & $45.94 \%$ \\
Consumer durables & $8.98 \mathrm{x}$ & $8.07 \mathrm{x}$ & $11.35 \%$ \\
Consumer nondurables & $11.19 \mathrm{x}$ & $11.11 \mathrm{x}$ & $0.69 \%$ \\
Consumer services & $10.33 \mathrm{x}$ & $8.66 \mathrm{x}$ & $19.34 \%$ \\
Distribution services & $11.24 \mathrm{x}$ & $8.91 \mathrm{x}$ & $26.06 \%$ \\
Electronic technology & $10.26 \mathrm{x}$ & $9.16 \mathrm{x}$ & $12.04 \%$ \\
Energy minerals & $8.48 \mathrm{x}$ & $4.97 \mathrm{x}$ & $70.65 \%$ \\
Health services & $11.89 \mathrm{x}$ & $11.15 \mathrm{x}$ & $6.65 \%$ \\
Health technology & $14.90 \mathrm{x}$ & $12.67 \mathrm{x}$ & $17.58 \%$ \\
Industrial services & $9.44 \mathrm{x}$ & $7.15 \mathrm{x}$ & $31.99 \%$ \\
Non-energy minerals & $9.21 \mathrm{x}$ & $6.49 \mathrm{x}$ & $41.97 \%$ \\
Process industries & $10.32 \mathrm{x}$ & $7.97 \mathrm{x}$ & $29.44 \%$ \\
Producer manufacturing & $10.34 \mathrm{x}$ & $8.30 \mathrm{x}$ & $24.63 \%$ \\
Retail trade & $9.06 \mathrm{x}$ & $7.55 \mathrm{x}$ & $20.07 \%$ \\
Technology services & $11.46 \mathrm{x}$ & $9.55 \mathrm{x}$ & $19.97 \%$ \\
Transportation & $9.36 \mathrm{x}$ & $7.40 \mathrm{x}$ & $26.50 \%$ \\
Utilities & $10.41 \mathrm{x}$ & $7.61 \mathrm{x}$ & $36.76 \%$ \\
Average & $\mathbf{1 0 . 3 9 x}$ & $\mathbf{8 . 4 6 x}$ & $\mathbf{2 5 . 5 8 \%}$ \\
\hline
\end{tabular}

Table 1 shows successful deals are usually closed at or above market multiples. In the absence of extreme agency conflicts, deals are possible only if they do not result in a certain loss for the acquirer. Hence, Table 1 suggests a considerable part of synergies is transferred to targets' shareholders on average. Thus, the relevant question is how much of the deal's synergy can the acquirer retain. Grossman and Hart (1980) suggest with symmetric information and a dispersed ownership of targets, all synergies should be included in the offering price. The argument underlying their claim is simple. Under the acquirer's ownership, if the value of the target firm's assets increases by $\pi>0$ per share, then accepting an offer that includes a premium less than $\pi$ would always be less rewarding than waiting for the deal's closing for the target's shareholders. Similarly, Leahy (1993) suggests more generally that in a competitive market, any external growth option is always exercised at-the-money; otherwise, another firm could exercise it at a marginally lower price while still retaining some positive value. Hence, we may say in the context of high competition, such as the current scenario featuring low economic growth and prolonged monetary stimulus, the so-called search for yield places a considerable obstacle to creating shareholder value through external growth options.(Note 6) Based on the previous considerations, we can express the value of the firm as

$$
V=V^{A}+D T S-B C,
$$

where the dynamics of the unlevered free cash flows generated by the assets in place and organic growth can be reasonably assumed independent of financing decisions.

The valuation of the DTS and $B C$ is often subject to ad-hoc assumptions regarding the firm's debt policy. Supporters of Leland's (1994) trade-off theory claim the existence of a target leverage ratio but omit the fact that Leland's model is based implicitly on the firm's commitment to avoid adjusting its amount of outstanding debt in the future. The classic discounted cash flows (DCF) model with a constant weighted average cost of capital (WACC) is an example of this approach. Unfortunately, the constant leverage hypothesis is both counterfactual and theoretically flawed, as shown by Admati, DeMarzo, Hellwig, and Pfleiderer (2017). To cite an example, if a negative fundamental shock impaired the value of the firm's operating assets, then shareholders should substitute debt financing with additional equity to keep the firm's leverage ratio constant. Clearly, this would be detrimental for shareholders because it would be equivalent to a net transfer of value to debtholders. (Note 7) From a more empirical 
perspective, firms tend to issue additional debt or renegotiate financing conditions before raising new equity or defaulting.

DeMarzo and He's (in press) groundbreaking article indirectly provides a solution to the valuation of $D T S-B C$ in practice. They show that if the firm cannot commit to a certain financing policy as an application of the Coase conjecture (1972), then the value of the equity can be obtained as if shareholders commit to not issuing additional debt in the future. Moreover, the value of the firm is strictly lower than its unlevered benchmark value because BC more than offset the value of the DTS. Intuitively, these extreme results depend on the model's continuous time setting, where the firm can issue additional debt any time in the future. By anticipating this behavior, debtholders are willing to buy the firm's debt only at yields that motivate the firm to issue additional debt aggressively so that any gain from trading is eventually dissipated in the Markov perfect equilibrium (MPE) of the dynamic game. A simplified proof of this result is provided in Appendix B. In reality, we know firms cannot issue debts continuously, so DeMarzo and He's (in press) theoretical result could be drastic. Based on this consideration, we assume expected default costs just offset the value of the DTS without causing a net loss. Consequently, we obtain the value of the firm as

$$
V=V^{A}=\mathbb{E}_{t} \int_{0}^{\infty} e^{\int_{0}^{s} \mu_{t+h} d h} x_{t+s} d s,(7)
$$

where $x_{t}$ denotes the periodic unlevered free cash flows generated by the assets in place and their organic evolution. (Note 8)

The next step is to specify a stochastic model for $x_{t}$ and $\mu_{t}$. If we look at our sample, especially in relation to the size of the global assets market, we notice the quite small weight of the largest security at each point in time. Therefore, the two-trees (Note 9) effects (Cochrane, Longstaff, and Santa-Clara, 2008) can be considered marginal. For the sake of simplicity, we can assume a constant cost of capital $\left(\mu_{t}=\mu\right)$ that may be a function of different firms' characteristics. Because we work on a large number of firms, we model $x_{t}$ as a geometric Brownian motion (GBM),

$$
d x_{t}=g x_{t} d t+\sigma x_{t} d W_{t},(8)
$$

where $g$ is the firm's growth rate, $\sigma$ represents a positive constant, and $W_{t}$ denotes a standard Brownian motion. Under the previous hypothesis, we can write the value of the firm as

$$
V_{t}=\frac{x_{t}}{\mu-g}, \text { (9) }
$$

which is essentially a sort of Gordon (1959) valuation model obtained from first principles: namely, the equilibrium analysis of inorganic growth's value and the trade-off between the value of the DTS and expected $B C$. This is of remarkable importance in our context because the size effect may be related to the weight of growth options, as suggested by Berk, Green and Naik (1999).

The implied cost of capital is then defined in accordance with equation (9). In other words, for each firm, it solves the following expression for the observed enterprise value and the current values of $g_{t}$ and $x_{t}$ :

$$
\mu=\frac{x_{t}}{v_{t}}+g .
$$

Note the implied cost of capital is equivalent to the unlevered cost of equity of the assets in place as a natural consequence of equation (7).

\section{Data and Methodology}

Financial markets have changed dramatically since the 2008 financial crisis. For this reason, we consider the past 10 years and focus on European listed companies in our study. The interest in the European market is driven by the combination of stagnant gross domestic product (GDP) growth and monetary stimulus, which supports the hypothesis underlying our valuation framework.

We obtained data from FactSet at a half-yearly frequency, considering the end of April and October for each year considered in the analysis; this covers the April 2010 to April 2020 period. The choice of April and October as reference dates relates to the availability of new fundamental data; European companies usually report their yearly or half-yearly results by the end of these two months. We consider the top 1,000 companies by market capitalization listed on primary European markets, which represent almost the totality of the investable universe's market capitalization. We exclude companies under the financial sector because of their business model's different nature and the impact of European regulation. The data set assembled in this way is composed of 15,171 half-yearly observations, where each data point corresponds to a different nonfinancial firm on a specific date. Using the FactSet Fundamentals and FactSet Estimates databases, we calibrate the different components of the right-hand side (RHS) 
of equation (10) to obtain the implied cost of capital for each firm in the sample on each different date $\left(\hat{\mu}_{i, t}\right)$. To compare all firms included in the sample, the data are converted to euros at historical exchange rates.

Starting from the denominator of the RHS of equation (10), consensus estimates for free cash flows usually include the effect of the tax shield on interest payments, which will not be included in the computation of $x_{t}$. Some analysts adopt different naming conventions, and data are not always available to estimate unlevered free cash flows. Given the long-term nature of our valuation model, we proxy the current value for $x_{t}$, starting from the consensus estimate for the EbIT (Note 10) of the current unreported fiscal year (FY1), which we write as $\mathbb{E}_{t}\left(E b I T_{y(t)+1}\right)$, where $y(t)$ denotes the last reported fiscal year on date (instant) $t$; we then subtract the expected change in invested capital (CapEX + Change in working capital).

We assume the return on invested capital (RoIC) follows a Martingale process, which is a plausible hypothesis if the firm is able to maintain its operating margin and capital efficiency over a short period. The RoIC measures the amount of operating profits that can be generated per unit of capital: that is, $\operatorname{EbIT}(t) / I C(t)$, where $I C(t)$ denotes the book value of the firm's operating assets. For simplicity, we also assume (a) changes in invested capital are locally deterministic, (Note 11) and (b) the expected growth of EbIT can be approximated with that of unlevered free cash flows, (Note 12) obtaining

$$
\mathbb{E}_{t}\left(I C_{t+d t}\right) \approx \mathbb{E}_{t}\left(\operatorname{EbIT}_{y(t)+1}\right) \frac{g_{t}}{\operatorname{RoIC}_{y(t)}},
$$

where the term $\frac{g_{t}}{\operatorname{RoIC}_{y(t)}}$ is the firm's plowback ratio. (Note 13) Hence, we can proxy $x_{t}$ as

$$
x_{t} \approx \mathbb{E}_{t}\left(\operatorname{EbIT}_{y(t)+1}\right)\left[(1-\tau)-\frac{g_{t}}{\operatorname{RoIC}_{y(t)}}\right],(12)
$$

where the $(1-\tau)$ component is intended to capture the effect of the tax paid on operating profits.

Because IC may have changed during the year of observation, we measure the RoIC in practice, averaging between the invested capital in two subsequent fiscal years:

$$
R O I C_{y}:=\frac{\text { EbIT }_{y}}{\frac{1}{2}\left(I C_{y-1}+I C_{y}\right)} .
$$

The company's invested capital is then obtained as $I C_{y}=B V_{y}+N F P_{y}$, where $B V_{y}$ and $N F P_{y}$ are the book value of the equity and the company's net financial position, respectively (that is, total debt minus cash hoardings). The sum of the equity book value of the net debt is clearly equal to the sum of the working capital and the book value of the fixed assets, which is the book value of the operating assets in place. Tax rates are obtained on each date, considering the reference country. Specifically, we consider the average of the last reported tax rate for all companies incorporated in the same country. (Note 14)

We then discuss our empirical strategy for measuring $g_{t}$ and $V_{t}$. Starting from the latter, the market value of all debt instruments is not always available. This is the case with bank loans, excepting a few instances of leveraged loans that are traded on the secondary market. Moreover, bond prices may be sticky, especially for instruments held by few investors (e.g., insurance companies holding corporate bonds for asset-liability management). However, for listed companies, default risk is generally quite limited; for the same reason, the market value of the debt can be approximated with its outstanding face value. Following this approach, we proxy $V$ as the sum of the firm's total equity market capitalization $\left(T M V E U R_{t}\right)$ plus that of its last reported net financial position $\left(N F P_{t}\right)$. For what concerns $g_{t}$, our model reduces the value of the firm to that of a growing perpetuity. In the very long run, firms that are expected to stay afloat must also be expected to grow at the same rate, broadly in line with the global GDP. Otherwise, if a firm grows at a rate higher than that of others, then it would become progressively account for nearly the totality of the GDP. Of course, an alternative is that one or more firms would grow at a rate below that of all the others, progressively disappearing because of their obsolescence. Because there is no obvious way to make a similar statement from an ex-ante perspective, we assume all firms grow at the same rate $g_{t}$, which is estimated on each date as the median of the last five years' compounded annual growth rate in sales (SALES_5Y). Because we are interested in organic growth only, for the purpose of estimating $g_{t}$, we consider only firms with single-digit growth (i.e., $\left|S_{A L E S} 5 Y\right|<10 \%$ ). This is an approximation, but systematically splitting the growth between its organic and nonorganic components is quite complex. Figure 1 shows the value of $g_{t}$ obtained for each date considered in the analysis. 


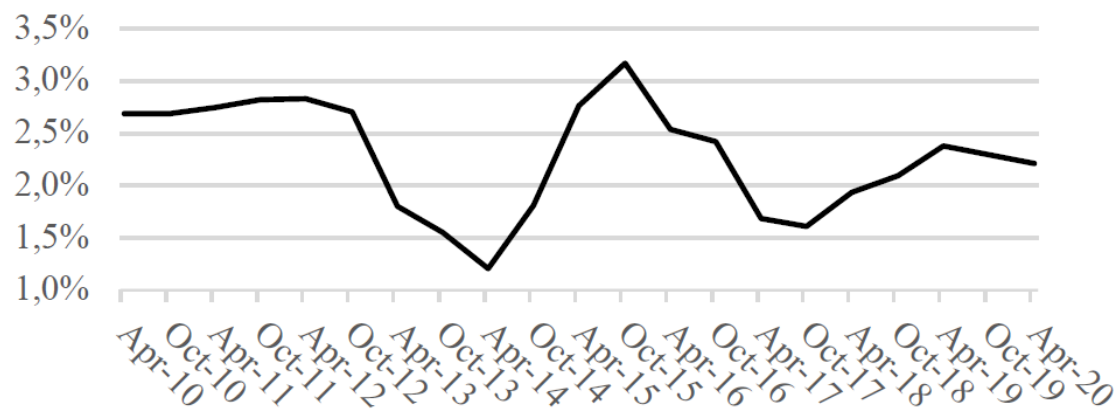

Figure 1. Long-term organic growth rate

We obtain the implied cost of capital $\left(\hat{\mu}_{i, t}\right)$ for each observation $(i, t)$ as

$$
\hat{\mu}_{i, t}=\frac{\mathbb{E}_{t}\left(E b I T_{y(i, t)+1}\right)\left[\left(1-\tau_{t, i}\right)-\frac{g_{t}}{\operatorname{RoIC}_{i, y(i, t)}}\right]}{\operatorname{TMVEUR}_{i, t}+N F P_{i, t}}+g_{t} .
$$

Considering only the data points with sufficient data to compute $\hat{\mu}_{i, t}, 15042$ panel observations were initially available. Observations with either negative EbIT or RoIC have been excluded because they cannot be reconciled with the stochastic process adopted to model the free cash flows dynamics. Similarly, observations with $\hat{\mu}_{i, t}$ below $0 \%$ or above $50 \%$ have been excluded from the analysis because such extreme values are driven by company fundamentals that are hardly consistent with our modeling strategy. These restrictions have resulted in the exclusion of 249 observations, which represent an acceptable empirical cost compared with the introduction of a more sophisticated cash flow process. Our sample ultimately comprises 14793 observations, for a total of 21 half-yearly cross-sections, each including on average 704 firms on each date.

We formulate a panel regression model to investigate which variables determine the implied cost of capital. As anticipated, the cost of capital is affected by the covariance between the firm's cash flows process and the economy's stochastic discount factor, which is hard to estimate in practice. For this reason, we split cash flows shocks $\left(\sigma d W_{t}\right)$ in two components: (a) a sector-specific component and (b) a firm-specific component that we assume is idiosyncratic. Because only systematic risk matters, we introduce sector dummies as a first proxy of cash flows risk in our regression model. Investors' risk aversion is a key determinant of the market risk premium, and it may vary in time as opposed to the classic, one-period CAPM. Because this effect should be comparable across firms, we control for exogenous changes in risk aversion, including time-fixed effects. According to CAPM-like theories of the cost of capital, these dummy variables should be sufficient to explain the cost of capital. However, consistent with the empirical asset pricing literature (see Cochrane, 2010), other factors may be particularly relevant, such as size, value, growth, and momentum. Next, we discuss how to identify suitable proxies for these factors, with particular attention to the related econometric identification.

Starting from size, the natural approach would be to consider the inclusion of $V$ as a control variable. Unfortunately, this would introduce a simultaneity bias in our regression model because $V$ is a function of the cost of capital. Hence, there is a considerable opportunity to observe a correlation between the two variables, which does not necessarily imply the existence of a causal effect. However, because growth options are unlikely to be the economic explanation for a potential small-sized effect, we may consider the firm's current revenue as a proxy for its economic dimension. In fact, the economic explanation for a possible small-sized premium would be the higher business risk for a smaller company compared to its larger competitors. Because (a) lower sales should be associated with a higher cost of capital, but (b) the effect should be simultaneously negligible for companies with sufficiently large revenues, we expect an inverse relation between the firm's size and the cost of capital. For this reason, we use the inverse of the last reported revenues measured in millions of euros (INV_SALES) as a proxy for the size factor.

In principle, the value factor could be introduced, considering the ratio between the enterprise value and the book value of the firm's invested capital, which is the "firm-side" equivalent of the price-to-book ratio. However, the presence of the firm's value in the numerator may introduce a simultaneity bias, as we have seen as a precedence. If we divide both sides of equation (9) by the firm's invested capital, then we notice the same ratio is a function of $\mu_{i, t}$ and $\operatorname{RoIC}_{i, t}$. Nevertheless, because $\operatorname{RoIC}_{i, t}$ should be only limitedly affected (Note 15) by $\mu_{i, t}$, we can use it as a proxy that allows the identification of the value factor in our regression analysis. 
Carhart (1997) shows the existence of a momentum effect; that is, stocks that have performed well recently tend to perform better on average in the future. We include momentum as a potentially relevant variable in our regression model and proxy it with the last six months' percentage change in each firm's stock price (PXMOM6M). We then introduce growth and liquidity factors in the analysis as additional control variables. Growth in sales is included to investigate the existence of a premium for companies that recently experienced more aggressive growth rates. The regressor that is included to measure this potential effect is the last five years' compounded average growth in total revenues (SALES_5Y). Finally, liquidity is measured, considering the impact of a one-million-euro trade on the stock, in terms of percentage participation in average traded volumes (IMPACT). Average volumes are computed, considering the last three months of daily trading data and including all exchange venues. The idea is that less liquid stock may be trading at a discount to compensate investors for potential lock-in periods and transaction costs (e.g., slippage). Because IMPACT could be a very large number in principle, we consider its natural logarithm in the regression $(\log ($ IMPACT)).

Our regression model is formulated as

$$
\begin{aligned}
& \hat{\mu}_{i, t}=\boldsymbol{\beta}_{\text {Sector }}^{\prime} \boldsymbol{\delta}_{i}+\boldsymbol{\beta}_{\text {Time }}^{\prime} \boldsymbol{t}_{t}+\beta_{\text {SIZE }} \text { INV_SALES }_{i, t}+\beta_{\text {VALUE }} \text { ROIC } C_{i, t}+\beta_{\text {MOMENTUM }} \text { PXMOM6M } \text { M }_{i, t}+ \\
& \beta_{\text {GROWTH }} \text { SALES }_{i, t}+\beta_{\text {LIQUIDITY }} \log \left(\text { ILLIQ }_{i, t}\right)+\varepsilon_{i, t},(15)
\end{aligned}
$$

where $\varepsilon_{i, t}$ is an error component with expected value equal to zero and conditionally mean independent of all the regressors. For each observation $(\mathrm{i}, \mathrm{t}), \delta_{\mathrm{i}}$ is a vector where each entry corresponds to a different sector. All entries are set equal to zero except the one corresponding to the reference sector of the considered company. In total, nine sectors are considered, consistent with those of the FTSE ICB1 classification: basic materials, consumer services, health care, technology, industrials, utilities, consumer goods, oil \& gas, and telecommunications. Notably, there is no need to include an intercept because we have a dummy for each sector. Similarly, time-fixed effects are introduced as a vector $\boldsymbol{t}_{t}$ of date-specific dummies.

\begin{tabular}{|c|c|c|c|c|c|c|}
\hline Variable & $\mathbf{V}$ & TMVEUR & $\mathbf{F}$ & SALES & EBIT & $\begin{array}{l}\text { E_EBIT_SAL } \\
\text { ES }\end{array}$ \\
\hline Description & $\begin{array}{l}\text { Enterprise } \\
\text { value (euro in } \\
\text { millions) }\end{array}$ & $\begin{array}{l}\text { Market } \\
\text { capitalization } \\
\text { (euro in } \\
\text { millions) }\end{array}$ & $\begin{array}{l}\text { Net debt } \\
\text { (euro in } \\
\text { millions) }\end{array}$ & $\begin{array}{l}\text { Revenues } \\
\text { (euro in } \\
\text { millions) }\end{array}$ & $\begin{array}{l}\text { EbIT (euro in } \\
\text { millions) }\end{array}$ & $\begin{array}{l}\text { EbIT/Sales, } \\
\text { FY1 consensus }\end{array}$ \\
\hline $\begin{array}{l}\text { Available } \\
\text { observations }\end{array}$ & 14795 & 14795 & 14795 & 14795 & 14795 & 14795 \\
\hline Average & 11751 & 9279 & 2472 & 9002 & 1018 & $13.66 \%$ \\
\hline $\begin{array}{l}\text { 25th } \\
\text { percentile }\end{array}$ & 1282 & 1020 & 14 & 934 & 106 & $6.67 \%$ \\
\hline Median & 3323 & 2678 & 338 & 2310 & 267 & $10.97 \%$ \\
\hline $\begin{array}{l}\text { 75th } \\
\text { percentile }\end{array}$ & 9479 & 7732 & 1515 & 7288 & 720 & $17.28 \%$ \\
\hline Variable & $\begin{array}{l}\text { E_EV_EBITD } \\
\text { A }\end{array}$ & $\begin{array}{l}\text { E_ND_EBITD } \\
\text { A }\end{array}$ & tax_rate & ROIC & g & ROE \\
\hline Description & $\begin{array}{l}\text { Enterprise } \\
\text { value-to-EbITD } \\
\text { A }\end{array}$ & $\begin{array}{l}\text { Net debt to } \\
\text { EbITDA, FY1 } \\
\text { consensus }\end{array}$ & $\begin{array}{l}\text { Corporate } \\
\text { tax rate }\end{array}$ & $\begin{array}{l}\text { Return on } \\
\text { invested } \\
\text { capital }\end{array}$ & $\begin{array}{l}\text { Organic } \\
\text { growth rate }\end{array}$ & $\begin{array}{l}\text { Return } \\
\text { equity }(\%)\end{array}$ \\
\hline $\begin{array}{l}\text { Available } \\
\text { observations }\end{array}$ & 14713 & 14791 & 14795 & 14795 & 14795 & 14627 \\
\hline Average & $9.33 x$ & $1.14 \mathrm{x}$ & $25.44 \%$ & $32.64 \%$ & $2.28 \%$ & $20.83 \%$ \\
\hline $\begin{array}{l}\text { 25th } \\
\text { percentile }\end{array}$ & $6.14 x$ & $0.02 x$ & $22.47 \%$ & $10.38 \%$ & $1.81 \%$ & $8.48 \%$ \\
\hline Median & $8.36 \mathrm{x}$ & $1.03 x$ & $25.47 \%$ & $16.11 \%$ & $2.38 \%$ & $13.52 \%$ \\
\hline
\end{tabular}

Table 2. Summarizes the main statistics of each variable included in our analysis 
75th

\begin{tabular}{|c|c|c|c|c|c|c|}
\hline percentile & $11.09 x$ & $2.04 \mathrm{x}$ & $28.38 \%$ & $24.94 \%$ & $2.71 \%$ & $20.41 \%$ \\
\hline Variable & mu & BP & $\begin{array}{l}\text { PXMOM6 } \\
\text { M }\end{array}$ & $\begin{array}{l}\text { SALES_5 } \\
\text { Y }\end{array}$ & $\begin{array}{l}\text { INV_IMPAC } \\
T\end{array}$ & FLT_PCT \\
\hline Description & $\begin{array}{l}\text { Implied cost of } \\
\text { capital }\end{array}$ & $\begin{array}{l}\text { Book-to-price } \\
\text { ratio }\end{array}$ & $\begin{array}{l}\text { Price } \\
\text { momentum } \\
6 \mathrm{M}\end{array}$ & $\begin{array}{l}\text { Revenue } \\
\text { growth, } \\
5 Y \text { CAGR }\end{array}$ & $\begin{array}{l}\text { Inverse } \\
\text { IMPACT }\end{array}$ & Free float $(\%)$ \\
\hline $\begin{array}{l}\text { Available } \\
\text { observations }\end{array}$ & 14795 & 14756 & 14772 & 13841 & 14795 & 14795 \\
\hline Average & $7.56 \%$ & $60.20 \%$ & $4.91 \%$ & $5.43 \%$ & 36.21 & $69.81 \%$ \\
\hline $\begin{array}{l}\text { 25th } \\
\text { percentile }\end{array}$ & $5.69 \%$ & $26.43 \%$ & $-8.18 \%$ & $0.12 \%$ & 1.52 & $47.20 \%$ \\
\hline Median & $7.01 \%$ & $43.38 \%$ & $4.17 \%$ & $4.45 \%$ & 7.12 & $73.84 \%$ \\
\hline $\begin{array}{l}\text { 75th } \\
\text { percentile }\end{array}$ & $8.69 \%$ & $72.41 \%$ & $17.37 \%$ & $9.08 \%$ & 27.29 & $95.26 \%$ \\
\hline
\end{tabular}

4. Results

After excluding observations where one or more regressors are unavailable, we are left with 13308 observations. This sample is used to estimate the coefficient of the regression model (15) using the panel ordinary least squares (OLS) estimator, which is consistent for the model's coefficient under our hypothesis. Confidence intervals are obtained using Driscoll and Kraay's (1998) standard errors, which are heteroskedasticity and autocorrelation (HAC) robust. The results are shown in Table 3.

Time-fixed effects are statistically significant, consistent with the hypothesis of the time-varying risk aversion. The regression has limited explaining power. The only coefficients that (a) are significant at any confidence level and (b) materially affect the cost of capital simultaneously are those associated with sector dummies. These coefficients correspond to the average cost of equity at the sector level, which appears within the plausible range of $6.5 \%-8.5 \%$. The results are also consistent with basic economic intuition and industry considerations.

Table 3. Panel OLS estimates for equation (15), Driscoll-Kray HAC standard errors

\begin{tabular}{lllllll}
\hline & Parameter & $\begin{array}{l}\text { Standard } \\
\text { error }\end{array}$ & T-stat & P-value & Lower CI & Upper CI \\
\hline Sector Dummy: Basic Materials & 0.0834 & 0.0023 & 36.979 & 0 & 0.079 & 0.0878 \\
Sector Dummy: Consumer Goods & 0.0774 & 0.0027 & 28.65 & 0 & 0.0721 & 0.0827 \\
Sector Dummy: Consumer Services & 0.0803 & 0.0019 & 41.493 & 0 & 0.0765 & 0.0841 \\
Sector Dummy: Health Care & 0.0649 & 0.0018 & 36.816 & 0 & 0.0614 & 0.0683 \\
Sector Dummy: Industrials & 0.0763 & 0.0008 & 95.012 & 0 & 0.0748 & 0.0779 \\
Sector Dummy: Oil \& Gas & 0.0844 & 0.0024 & 35.674 & 0 & 0.0798 & 0.089 \\
Sector Dummy: Technology & 0.0748 & 0.0011 & 67.581 & 0 & 0.0727 & 0.077 \\
Sector Dummy: Telecommunications & 0.0682 & 0.0012 & 55.5 & 0 & 0.0658 & 0.0706 \\
Sector Dummy: Utilities & 0.065 & 0.0017 & 38.296 & 0 & 0.0617 & 0.0684 \\
INV_SALES & -0.1903 & 0.1109 & -1.715 & 0.0864 & -0.4077 & 0.0272 \\
ROIC & 0.0002 & $8.89 \mathrm{E}-05$ & 2.4347 & 0.0149 & $4.22 \mathrm{E}-05$ & 0.0004 \\
PXMOM6M & -0.0136 & 0.0027 & -5.1209 & 0 & -0.0188 & -0.0084 \\
SALES_5Y & 0.0142 & 0.0031 & 4.5206 & 0 & 0.008 & 0.0203 \\
LOG(IMPACT) & 0.0005 & 0.0005 & 0.98 & 0.3271 & -0.0005 & 0.0014 \\
& & & & & &
\end{tabular}




\begin{tabular}{lccll}
\hline F-test for poolability: 17.962 & $\mathrm{R} 2$ & 0.0388 & F-statistic: & 42.819 \\
& $\mathrm{R} 2$ & & & \\
P-value: 0.0000 & (Between) & 0.0378 & P-value & 0 \\
& R2 & & & \\
Distribution: F (20,13 776) & (Within) & 0.0333 & Distribution: & F (13,13 776) \\
\hline
\end{tabular}

Sectors that are less exposed to the economic cycle, such as telecommunications and utilities, pay a lower cost of capital, roughly $1 \%$ below average. By contrast, sectors such as basic materials and oil \& gas must compensate investors with an additional premium, consistent with their greater cyclicality.

Ultimately, we find that size has a limited statistical significance (P-value > 5\%) and a negligible effect. To cite an example, consider two companies, A and B, that differ only in the amount of their revenues. If Company A has revenues of 200 million euros, whereas Company B's revenues amount to 10 billion euros, the latter should pay a premium, relative to Company $\mathrm{A}$, equal to $\beta_{S I Z E}\left(I N I_{-} S A L E S_{A, t}-I N V_{-} S A L E S_{B, t}\right) \approx-0.1903\left(\frac{1}{10,000}-\frac{1}{200}\right)=$ $0.0931 \% \approx 9 \mathrm{bps}$. Hence, despite the moderate statistical significance of the size coefficient, a very small business should compensate investors annually with just 9 additional basis points (bps) compared with a very large player under the same industry and with the same characteristics. Even if we consider the bottom end of the $95 \%$ confidence interval for the estimate of $\beta_{S I Z E}$, we arrive at roughly $20 \mathrm{bps}$, which is still a negligible premium considering the enormous difference between the two companies' sizes. Hence, the small-size effect is wholly irrelevant in practice; that is, investors on average do not ask smaller companies to pay an additional premium. It is important to recognize that this result holds for listed companies and cannot be extrapolated to the case of private firms. In particular, the valuation of a private company may include a size premium as a proxy for higher liquidity risk.

Matters become even more interesting when examining value. Ceteris paribus, companies with higher RoIC should have higher multiples. The classic value anomaly predicts companies with lower multiples should yield more, ceteris paribus. Here we find exactly opposite evidence, although the effect of this coefficient is entirely marginal, just as for the small-size effect. To cite an example, doubling the RoIC results in an increase of a few bps in the cost of capital, which is again a completely negligible effect. Similar considerations hold true for momentum (PX6MOM) and growth (SALES_5Y), although the sign of the PX6MOM coefficient suggests the presence of some sort of mean reversion. Nevertheless, the magnitude of both coefficients suggests growth and momentum do not affect how investors determine the cost of capital for European listed companies.

One possible explanation for the observed relation between the cost of capital and ROIC is provided by Zhang's (2017) Investment CAPM, which predicts a larger cost of capital for companies with higher profitability and low investments-to-assets ratio. In the Investment CAPM, each firm optimally expands its output capacity until the marginal benefit of an additional unit of invested capital is equal to the its cost of capital. As a consequence, low investments firms with high profitability (high ROIC) must have, ceteris paribus, a higher cost of capital. In this regard, since we do not control for the investments-to-assets factor (Zhang, 2017), the positive effect of ROIC may have been underestimated in our regression analysis.

Generally, it is quite uncommon to observe coefficients that appear statistically significant but still have null explaining power, despite the strict exogeneity of all regressors. A potential explanation is that standard errors are not sufficiently large because of the limited time depth of our data set. In this regard, if we compute clustered standard errors, introducing both time and entity clusters, we find the size effect is no longer significant at any reasonable confidence level (P-value $>10 \%$ ), as shown in Table 4. Based on this additional evidence, we conclude the small-sized premium is not present in the most recent history of the European equity market, consistent with A. Ang (2014) and C. Ang (2018), at least from an ex-ante perspective. 
Table 4. Panel OLS estimates for equation (15), clustered standard errors

\begin{tabular}{|c|c|c|c|c|c|c|}
\hline & Parameter & $\begin{array}{l}\text { Standard } \\
\text { error }\end{array}$ & T-stat & P-value & Lower CI & Upper CI \\
\hline Sector Dummy: Basic Materials & 0.0834 & 0.0047 & 17.651 & 0 & 0.0741 & 0.0927 \\
\hline Sector Dummy: Consumer Goods & 0.0774 & 0.0029 & 26.461 & 0 & 0.0716 & 0.0831 \\
\hline Sector Dummy: Consumer Services & 0.0803 & 0.0029 & 27.763 & 0 & 0.0746 & 0.086 \\
\hline Sector Dummy: Health Care & 0.0649 & 0.0025 & 25.541 & 0 & 0.0599 & 0.0699 \\
\hline Sector Dummy: Industrials & 0.0763 & 0.0015 & 50.996 & 0 & 0.0734 & 0.0793 \\
\hline Sector Dummy: Oil \& Gas & 0.0844 & 0.0045 & 18.555 & 0 & 0.0755 & 0.0933 \\
\hline Sector Dummy: Technology & 0.0748 & 0.0027 & 27.902 & 0 & 0.0696 & 0.0801 \\
\hline Sector Dummy: Telecommunications & 0.0682 & 0.0028 & 24.098 & 0 & 0.0627 & 0.0738 \\
\hline Sector Dummy: Utilities & 0.065 & 0.0029 & 22.802 & 0 & 0.0595 & 0.0706 \\
\hline INV_SALES & -0.1903 & 0.1274 & -1.4939 & 0.1352 & -0.4399 & 0.0594 \\
\hline ROIC & 0.0002 & $1.00 \mathrm{E}-04$ & 2.1153 & 0.0344 & $1.59 \mathrm{E}-05$ & 0.0004 \\
\hline PXMOM6M & -0.0136 & 0.0021 & -6.6161 & 0 & -0.0176 & -0.0096 \\
\hline SALES_5Y & 0.0142 & 0.0047 & 3.0241 & 0.0025 & 0.005 & 0.0233 \\
\hline np.log (IMPACT) & 0.0005 & 0.0005 & 0.8569 & 0.3915 & -0.0006 & 0.0015 \\
\hline F-test for poolability: 17.962 & $\mathrm{R} 2$ & 0.0388 & & & & \\
\hline P-value: 0.0000 & $\begin{array}{c}\mathrm{R} 2 \\
\text { (Between) }\end{array}$ & 0.0378 & & & & \\
\hline Distribution: F $(20,13776)$ & $\begin{array}{c}\mathrm{R} 2 \\
\text { (Within) }\end{array}$ & 0.0333 & & & & \\
\hline
\end{tabular}

\section{Conclusions}

We have shown how to compute the implied cost of capital for European listed companies and have tested for the existence of a size effect through panel regressions, including time-fixed effects. Our results indicate that from an ex-ante perspective, the implied cost of capital is not affected by the firm's size; this is consistent with C. Ang's (2018) findings. Quantitatively, the same consideration holds for other factors, such as value or momentum, having included sector dummies as proxies for a firm's systematic cash flow risk. Our results should not be generalized out of the space of listed companies, specifically to the valuation of private assets, where size could be an efficient proxy for liquidity risk.

\section{References}

Admati, A., DeMarzo, P., Hellwig, M., \& Pfleiderer, P. (2017). The leverage ratchet effect. Journal of Finance, 73(1), 145-198. https://doi.org/10.1111/jofi.12588

Ang, A. (2014). Asset management. Oxford: Oxford University Press. https://doi.org/10.1093/acprof:oso/9780199959327.001.0001

Ang, C. (2018). The absence of a size effect relevant to the cost of equity. Business Valuation Review, 37(3), 87-92. https://doi.org/10.5791/BVR-D-17-00013.1

Banz, R. (1981). The relationship between return and market value of common stocks. Journal of Financial Economics, 9(1), 3-18. https://doi.org/10.1016/0304-405X(81)90018-0

Berk, J., Green, R., \& Naik, V. (1999). Optimal investment, growth options, and security returns. Journal of Finance, 54(5), 1553-1607. https://doi.org/10.1111/0022-1082.00161

Bini, M. (2018). Implied cost of capital: How to calculate it and how to use it. Business Valuation OIV Journal, O(0), 5-32.

Black, F. (1993). Beta and return. Journal of Portfolio Management, 20(1), 8-18. https://doi.org/10.3905/jpm.1993.409462 
Carhart, M. M. (1997). On persistence in mutual fund performance. Journal of Finance, 52(1), 57-82. https://doi.org/10.2307/2329556

Chaderina, M., Weiss, P., \& Zechner, J. (2020). The maturity premium. SSRN Electronic Journal. https://doi.org/10.2139/ssrn.3283771

Coase, R. (1972). Durability and monopoly. Journal of Law and Economics, 15(1), $143-149$. https://doi.org/10.2307/725018

Cochrane, J. (2008). Asset pricing. Princeton: Princeton University Press.

Cochrane, J. (2011). Presidential address: Discount rates. Journal of Finance, 66(4), 1047-1108. https://doi.org/10.1111/j.1540-6261.2011.01671.x

Cochrane, J., Longstaff, F., \& Santa-Clara, P. (2007). Two trees. Review of Financial Studies, 21(1), 347-385. https://doi.org/10.1093/rfs/hhm059

Damodaran, A. (2015, April 11). The small cap premium: Where is the beef? Musings on Markets. [Blog post]. $\begin{array}{llll}\text { Retrieved July } & 24, & 2020 & \text { from }\end{array}$ http://aswathdamodaran.blogspot.com/2015/04/the-small-cap-premium-fact-fiction-and.html

DeMarzo, P., \& He, Z. (in press). Leverage dynamics without commitment. Journal of Finance.

Driscoll, J., \& Kraay, A. (1998). Consistent covariance matrix estimation with spatially dependent panel data. Review of Economics and Statistics, 80(4), 549-560. https://doi.org/10.1162/003465398557825

Duffie, D., \& Skiadas, C. (1994). Continuous-time security pricing. Journal of Mathematical Economics, 23(2), 107-131. https://doi.org/10.1016/0304-4068(94)90001-9

Duffie, D., \& Zame, W. (1989). The consumption-based capital asset pricing model. Econometrica, 57(6), 1279-1297. https://doi.org/10.2307/1913708

Dumas, B., \& Luciano, E. (2017). The economics of continuous-time finance (1st ed.). Cambridge (MA): MIT Press.

Easton, P. (2007). Estimating the cost of capital implied by market prices and accounting data. Foundations and Trends® in Accounting, 2(4), 241-364. https://doi.org/10.1561/1400000009

Easton, P. (2016). Estimating the cost of capital using stock prices and near-term earnings forecasts. Journal of Applied Corporate Finance, 28(3), 87-94. https://doi.org/10.1111/jacf.12195

Easton, P., Taylor, G., Shroff, P., \& Sougiannis, T. (2002). Using forecasts of earnings to simultaneously estimate growth and the rate of return on equity investment. Journal of Accounting Research, 40(3), 657-676. https://doi.org/10.1111/1475-679X.00066

Fama, E., \& French, K. (1993). Common risk factors in the returns on stocks and bonds. Journal of Financial Economics, 33(1), 3-56. https://doi.org/10.1016/0304-405X(93)90023-5

Feng, G., Giglio, S., \& Xiu, D. (2020). Taming the factor zoo: A test of new factors. Journal of Finance, 75(3), 1327-1370. https://doi.org/10.1111/jofi.12883

Glover, B. (2016). The expected cost of default. Journal of Financial Economics, 119(2), $284-299$. https://doi.org/10.1016/j.jfineco.2015.09.007

Gordon, M. (1959). Dividends, earnings, and stock prices. Review of Economics and Statistics, 41(2), 99-105. https://doi.org/10.2307/1927792

Grossman, S., \& Hart, O. (1980). Takeover bids, the free-rider problem, and the theory of the corporation. Bell Journal of Economics, 11(1), 42-64. https://doi.org/10.2307/3003400

Hellwig, M. F. (1977). On the validity of the intertemporal capital asset pricing model, Center for Operations Research and Econometrics (CORE) discussion paper 7744.

Jensen, M., \& Meckling, W. (1976). Theory of the firm: Managerial behavior, agency costs and ownership structure. Journal of Financial Economics, 3(4), 305-360. https://doi.org/10.1016/0304-405X(76)90026-X

Leahy, J. (1993). Investment in competitive equilibrium: The optimality of myopic behavior. Quarterly Journal of Economics, 108(4), 1105-1133. https://doi.org/10.2307/2118461

Leland, H. (1994). Corporate debt value, bond covenants, and optimal capital structure. Journal of Finance, 49(4), 1213-1252. https://doi.org/10.2307/2329184 
Lintner, J. (1965). The valuation of risk assets and the selection of risky investments in stock portfolios and capital budgets. Review of Economics and Statistics, 47(1), 13-37. https://doi.org/10.2307/1924119

Ma, C. (2011). Advanced asset pricing theory. London: Imperial College Press. https://doi.org/10.1142/p745

Martin, I. (2013). The Lucas Orchard. Econometrica, 81(1), 55-111. https://doi.org/10.3982/ECTA8446

Merton, R. (1973). An intertemporal capital asset pricing model. Econometrica, 41(5), 867-887. https://doi.org/10.2307/1913811

Miller, M., \& Modigliani, F. (1958). The cost of capital, corporate finance, and the theory of investment. American Economic Review, 3(48), 261-297.

Mossin, J. (1966). Equilibrium in a capital asset market. Econometrica, 34(4), 768-783. https://doi.org/10.2307/1910098

Myers, S. (1977). Determinants of corporate borrowing. Journal of Financial Economics, 5(2), 147-175. https://doi.org/10.1016/0304-405X(77)90015-0

Reindl, J., Stoughton, N., \& Zechner, J. (2013). Market Implied Cost of Bankruptcy. CFS working paper series 2013/27, Center for Financial Studies (CFS). https://doi.org/10.2139/ssrn.2324097

Reinganum, M. (1983). The anomalous stock market behavior of small firms in January. Journal of Financial Economics, 12(1), 89-104. https://doi.org/10.1016/0304-405X(83)90029-6

Sharpe, W. (1964). Capital asset prices: A theory of market equilibrium under conditions of risk. Journal of Finance, 19(3), 425-442. https://doi.org/10.2307/2977928

Zhang, L. (2017). The Investment CAPM. European Financial Management, 23(4), 545-603. https://doi.org/10.1111/eufm.12129 


\section{Appendix A}

Under a few technical hypotheses, the stochastic discount factor of the economy can be used to define a new probability measure $\mathbb{Q}$, equivalent to the objective one, under which all asset prices can be represented as

$$
p_{t}=\mathbb{E}_{t}^{\mathbb{Q}} \int_{0}^{\infty} e^{-\int_{0}^{s} r_{t+h} d h} x_{t+s} d s,
$$

where $r_{t}$ is the periodic risk-free rate, which we assume here as constant and equal to $r>0$. Suppose the firm has only two outstanding securities - equity and debt — and the amount of outstanding debt $\left(F_{t}\right)$ evolves smoothly as in DeMarzo and He (2020),

$$
d F_{t}=\left(G_{t}-\zeta F_{t}\right) d t,(17)
$$

where $G_{t}$ is the rate at which new debt is issued, which we take as given for the purpose of valuing the firm. The parameter $\zeta$ is instead debt's contractual retirement rate, as we model it for simplicity as an exponentially maturing perpetuity. All debt securities are assumed of equal seniority, unprotected (no covenants, no collateral), and with the same coupon rate $(c)$. The result presented here holds more in general and does not require the assumptions introduced so far to keep the discussion self-contained.

Let $x_{t}$ be the firm's free cash flows before the effect of the tax shield on interest payments, $\pi(x, F)$. We decompose $x_{t}$ into two components, $x_{t}^{A}$ and $x_{t}^{G}$, such that $x_{t}=x_{t}^{A}+x_{t}^{G}$. Both follow a drift diffusion process under the risk-neutral probability measure $\mathbb{Q}$,

$$
\begin{gathered}
d x_{t}^{A}=g^{A}\left(x_{t}\right) d t+\sigma^{A}\left(x_{t}\right) d W_{t}^{\mathbb{Q}} \\
d x_{t}^{G}=g^{G}\left(x_{t}, F_{t}\right) d t+\sigma^{G}\left(x_{t}, F_{t}\right) d W_{t}^{\mathbb{Q}},
\end{gathered}
$$

which we both take as given for the purpose of valuing the firm. The dependency of $g, \sigma$ on the amount of outstanding debt serves to highlight the fact that capital structure decisions may affect investment decisions; $x_{t}^{A}$ may be interpreted as the cash flows generated by the assets in place and their organic growth, while $x_{t}^{G}$ may be interpreted as those coming from inorganic growth options. The latter may be affected by agency costs of debt. For example, Myers's (1977) debt-overhang effect could be represented as $g_{F}^{G}<0$, while Jensen and Meckling's (1976) risk shifting could be represented as $\sigma_{F}^{G}>0$. Note we now use subscripts to denote partial derivatives rather than an explicit time dependency, consistent with the notation usually adopted in the corporate finance literature.

Equation (16) can be used to obtain the value of equity $V^{E}$ and the price of debt $p$. Respectively, the relevant cash flows are dividends, which are equal to $x-(c+\zeta) F+\pi+p G$, and coupon plus principal payments, $c+\zeta$. Differentiating equation (16) and applying Ito's lemma, we can write the following Hamilton-Jacobi-Bellman (HJB) equation for the value of equity and the price of debt, respectively,

$$
r V^{E}=x-(c+\zeta) F+\pi(y, F)+p G+[G-\zeta F] V_{F}^{E}+\underset{\text { Dividends payment }}{\breve{b}}+g V_{x}^{E}+\frac{1}{2} \sigma^{2} V_{x x}^{E}
$$

and

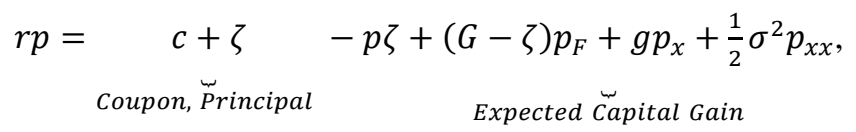

where $g:=g^{A}+g^{G}$ and $\sigma:=\sigma^{A}+\sigma^{G}$. Both equations are clearly valid in the continuation region (that is, as long as the firm does not default on its debt payments). The default time $t_{d}$ is taken as given for the purpose of valuing the firm. The bankruptcy process is modeled here as a simple liquidation procedure in which all growth options are lost, and debtholders obtain a fraction $(1-\alpha)$ of an unlevered firm value that includes only the value of assets in place; these include, as anticipated, the related organic growth. The value of an unlevered firm $\left(V_{t}^{u, A}\right)$ that includes only the assets in place is clearly equal to $\mathbb{E}_{t}^{\mathbb{Q}} \int_{0}^{\infty} e^{-r(s-t)} x_{t+s}^{A} d s$.

Let $t_{d}$ be the random default time and $V_{t}:=V_{t}^{E}+p_{t} F_{t}$ be the value of the firm. Then,

$$
V_{t}=V_{t}^{u, A}+\mathbb{E}_{t}^{\mathbb{Q}} \int_{t}^{t_{d}} e^{-r(s-t)} x_{t+s}^{G} d t+\mathbb{E}_{t}^{\mathbb{Q}} \int_{t}^{t_{d}} e^{-r(s-t)} \pi_{t} d t-\mathbb{E}_{t}^{\mathbb{Q}}\left[\alpha e^{-r\left(t_{d}-t\right)} V_{t_{d}}^{u, A}\right] .
$$

To see this, we multiply both sides of equation (6) by $F$,

$$
r p F=c F+(1-p) \zeta F+\theta F+(G-\zeta) p_{F} F+g p_{x} F+\frac{1}{2} \sigma^{2} p_{x x} F,
$$

and add each side of the previous equation to the respective sides of (7), obtaining 


$$
\begin{aligned}
r V=x & +\pi(x, F)+\left[(G-\zeta F) V_{F}^{E}+(G-\zeta) p_{F}+p G\right] \\
& +\left[g\left(V_{x}^{E}+p_{x} F\right)+\frac{1}{2} \sigma^{2}\left(V_{x x}^{E}+p_{x x} F\right)\right]
\end{aligned} .
$$

In the previous equation, $(G-\zeta F) V_{F}^{E}+(G-\zeta) p_{F}+p G$ is the expected partial change of $V=V^{E}+p F$ due to the change in the amount of outstanding debt $\left(d F_{t}\right)$, while $g\left(V_{x}^{E}+p_{x} F\right)+\frac{1}{2} \sigma^{2}\left(V_{x x}^{E}+p_{x x} F\right)$ is the expected partial change of $V=V^{E}+p F$ associated with $d x_{t}$. Applying the Feyman-Kac lemma, we can write the value of the firm as

$$
V_{t}=\mathbb{E}_{t}^{\mathbb{Q}} \int_{t}^{t_{d}} e^{-r(s-t)} x_{t+s}^{A} d t+\mathbb{E}_{t}^{\mathbb{Q}} \int_{t}^{t_{d}} e^{-r(s-t)} x_{t+s}^{A} d t+\mathbb{E}_{t}^{\mathbb{Q}} \int_{t}^{t_{d}} e^{-r(s-t)} \pi_{t} d t+\mathbb{E}_{t}^{\mathbb{Q}}\left[(1-\alpha) e^{-r\left(t_{d}-t\right)} V_{t_{d}}^{u, A}\right],
$$

where we use the fact that at default, $V_{t_{d}}=(1-\alpha) V_{t_{d}}^{u, A}$. Because $V_{t_{d}}^{u, A}$ is equal to $\mathbb{E}_{t_{d}}^{\mathbb{Q}} \int_{t_{d}}^{\infty} e^{-r\left(s-t_{d}\right)} x_{t+s}^{A} d s$, we obtain equation (22), where $\mathbb{E}_{t}^{\mathbb{Q}} \int_{t}^{t_{d}} e^{-r(s-t)} x_{t+s}^{G} d t$ is the value of the firm's inorganic growth options $\left(V^{G}\right)$; $\mathbb{E}_{t}^{\mathbb{Q}} \int_{t}^{t_{d}} e^{-r(s-t)} \pi_{t} d t$ represents the value of the debt tax shield (DTS); and $\mathbb{E}_{t}^{\mathbb{Q}}\left[\alpha e^{-r\left(t_{d}-t\right)} V_{t_{d}}^{u, A}\right]$ signifies the expected bankruptcy costs $(B C)$. For notational simplicity, in Section 3 we use $V^{A}$ to denote $V_{t}^{u, A}=$ $\mathbb{E}_{t}^{\mathbb{Q}} \int_{0}^{\infty} e^{-r(s-t)} x_{t+s}^{A} d s$. This observation concludes the proof of equation (5) in Section 3.

\section{Appendix B}

Because the value of growth options is null, we can assume without any loss of generality that $x_{t}=x_{t}^{A}$. For simplicity, we also assume that $\alpha=1$; that is, debtholders recover nothing in the bankruptcy process, although the model can be generalized further. This assumption is somewhat technical, but its role can be understood easily from the fact that it makes debt seniority irrelevant in the bankruptcy resolution process.

Shareholders optimally choose $G_{t}$ and a boundary value $b$ for $x_{t}$, at which they default on principal and coupon payments. DeMarzo and He (in press) conjecture and verify that the price of debt decreases in the amount of outstanding debt; that is, $p_{F}<0$, which is a quite obvious condition because a higher debt is likely to increase the probability of default, ceteris paribus. That said, shareholders solve the following optimization problem:

$$
r V^{E}=\max _{b, G}\left\{x-(c+\zeta) F+d t s(x, F)+p G+[G-\zeta F] V_{F}^{E}+g V_{x}^{E}+\frac{1}{2} \sigma^{2} V_{x x}^{E}\right\} .
$$

Because the objective is linear in $G$, in any smooth equilibrium it must be $p=-V_{F}^{E}$, which implies shareholders choose the default boundary, as in the case of commitment to $G_{t}=0$,

$$
r V^{E}=\max _{b}\left\{x-(c+\zeta) F+d t s(x, F)-\zeta F V_{F}^{E}+g V_{x}^{E}+\frac{1}{2} \sigma^{2} V_{x x}^{E}\right\}
$$

because at default, shareholders still recover nothing. Because the expression in brackets, $x-(c+\zeta) F+$ $d t s(x, F)-\zeta F V_{F}^{E}+g V_{x}^{E}+\frac{1}{2} \sigma^{2} V_{x x}^{E}$, is equivalent to dividends plus capital gain in case of commitment to $G_{t}=0$, the value of equity is the same as if the firm commits to not issuing additional debt in the future. This means when the firm has no outstanding debt, $V^{E}\left(x_{t}, F_{t}=0\right)=V_{t}^{A}=\mathbb{E}_{t}^{\mathbb{Q}} \int_{0}^{\infty} e^{-r(s-t)} x_{t+s}^{A} d s$.

From an asset-side perspective, the value of the firm is equal to $V=V^{E}+p F=V^{A}+D T S-B C$. Differentiating the previous expression with respect to $F$, we obtain

$$
V_{F}^{E}+p F+p_{F} F=D T S_{F}-B C_{F}
$$

because $V^{A}$ does not depend on $F$. Because in equilibrium $p=-V_{F}^{E}$, it follows that

$$
p_{F} F=D T S_{F}-B C_{F} \cdot(30)
$$

Integrating both sides of equation (30) between 0 and $F_{t}$, we obtain

$$
\operatorname{DTS}\left(x, F_{t}\right)-B C\left(x, F_{t}\right)=\int_{0}^{F_{t}} p_{F}(x, F) F d F
$$

as $\operatorname{DTS}(x, 0)-B C(x, 0)=0$, consistent with $V^{E}\left(x_{t}, F_{t}=0\right)=\mathbb{E}_{t}^{\mathbb{Q}} \int_{0}^{\infty} e^{-r(s-t)} x_{t+s}^{A} d s$. Because $p_{F}<0$, it follows that $\int_{0}^{F_{t}} p_{F}(x, F) F d F<0$. Hence, debt is issued in equilibrium at such an aggressive rate that expected bankruptcy costs more than offset the value of the debt tax shield. From a liability-side perspective, while shareholders gain nothing compared with the case of commitment, debtholders anticipate future debt issuances and price debt lower than in the case of commitment. This behavior reflects the drastic increase in default risk compared with the case where $G_{t}=0$. 


\section{Notes}

Note 1. Here, the word "equilibrium" means individuals trade in financial assets to maximize their utility, and all the resulting trades are mutually compatible (e.g., the purchased quantity of one asset is equal to the amount of the same assets that are sold). In particular, we focus on rational expectation equilibria, as common in the asset pricing literature.

Note 2. To derive the classic net present value statement in a continuous time setting, it is customary to restrict cash flows to the class of Ito diffusion processes.

Note 3. Consistent with asset pricing literature, by opportunity set, we mean the first- and the second-order moments of the distribution of asset returns.

Note 4. Essentially, consider the case of a representative investor with constant relative risk aversion. In equilibrium, the representative investor is holding its optimal portfolio, which has constant weights if the returns' distribution is stationary. This means if an asset's price increases because of a fundamental positive shock, then the investor would like to hold less of the same asset at the same expected return. For this to be possible in general equilibrium, the investor must be able to "redeem" part of its investment in the same asset, as in the case of linear technologies.

Note 5. This means earnings before interests, taxes, depreciation, and amortization.

Note 6. If one has the chance to read sell-side reports, it is unlikely that one will find valuations that include a tangible price component related to M\&A growth optionality, with the exception of very specific cases.

Note 7. The firm has the monopoly of its own debt. Reducing the outstanding supply of debt increases its price because the risk of default is reduced. The corresponding amount in the debt's price must be paid by shareholders to buy back debt from the market, resulting in a net loss of equity value. See Admati, DeMarzo, Hellwig, and Pfleiderer (2017) for more details.

Note 8. Equation (7) is basically a sort of Modigliani-Miller (1958) "irrelevance" result, which is enriched by additional equilibrium considerations about the value of inorganic growth, consistent with empirical evidence.

Note 9. See the previous section. Basically, if the price of a stock increases, its weight increases as well, also becoming riskier for the representative investor. This results in a demand for higher expected returns or equivalently, a multiple contraction. Nevertheless, this effect is mostly important at asset class levels because the weight of a single security is negligible compared with the others.

Note 10. This is earnings before interests and taxes.

Note 11 . This is certainly an approximation because a change in the working capital depends on the actual growth in revenues, which is stochastic.

Note 12. This is a reasonable approximation for firms that can adjust their production capacity at the margin.

Note 13. The reader may have noticed the similarity to the classic textbook formula in computing the plowback ratio on earnings to obtain expected dividends in a standard Gordon growth model. Our valuation model can be viewed as a Gordon model for the entire firm value.

Note 14. This methodology may be slightly biased for specific countries, especially the Netherlands. In fact, several companies have moved their headquarters to the Netherlands because of its double voting system while remaining tax residents in their original country. Nevertheless, the error is marginal because the Dutch tax rate for corporate income above 200,000 euros is $25 \%$, in line with the sample's average (25.44\%).

Note 15. If the firm's assets in place are largely the result of past acquisitions, then the valuation of goodwill may have an effect; this can be considered marginal in any case in terms of the resulting simultaneity bias. 